\title{
A TABU SEARCH APPROACH FOR THE BI-OBJECTIVE HOSPITAL SITE DETERMINATION PROBLEM UNDER FUZZY ENVIRONMENT
}

\author{
Nidhi Joshi ${ }^{1}$, Surjeet Singh Chauhan (Gonder) ${ }^{2}$, Raghu Raja ${ }^{3}$ \\ Research Scholar, PTU, Jalandhar \\ nids_22@yahoo.co.in \\ Department of Applied Science, Chandigarh Group of Colleges, Mohali, Punjab, India \\ surjeetschauhan@yahoo.com \\ Financial Services, Accenture \\ raghu.raja001@gmail.com
}

ABSTRACT

\begin{abstract}
The present paper attempts to study the bi-objective hospital site determination problem under fuzzy environment. In this paper, the concept of Tabu search is used for solving bi-objective facility location problem i.e. the most suitable hospital site to be searched out of the various possible sites nearest to the accidental prone areas so as to minimize the total transportation cost along with the transportation time using triangular fuzzy numbers. For this, we first search the hospital sites near accidental prone areas and then on the basis of that we obtain various optimal solutions with different transportation costs and times.
\end{abstract}

\section{Indexing terms/Keywords}

Optimization; Fuzzy Bi-Objective transportation problem; Ranking function; Triangular fuzzy number; Optimal solution; Tabu Search.

\section{Academic Discipline and Sub-Disciplines}

Mathematics and Fuzzy transportation problem

\section{MATHEMATICS SUBJECT CLASSIFICATION}

90C08, 90C90

\section{TYPE (METHOD/APPROACH)}

Illustration of proposed algorithm using numerical example.

\section{INTRODUCTION}

In operations research, the models representing transportation problems or facility location problems, etc. catering the real world situations always involve some parameters whose values are not exact and are to be assigned by the experts and decision makers. In conventional approach, the aforementioned parameters were fixed to an exact value by decision makers and experts. However, these values fixed by them are only the statistical inferences from the past data and these are not very accurate. To obtain the accurate values of these imprecise and vague parameters, the concept of fuzzy sets was introduced by Zadeh [5] in 1965. In 1970, Bellman and Zadeh [1], used this concept of fuzzy sets for evaluating the optimization techniques under fuzzy environments. Dubois and Parade in 1980 [6], first used these optimization techniques under fuzzy environment for solving transportation problems. Since then, tremendous significant advances have been done for the development of various methodologies and their applications in various fields involving real world problems.

Location allocation problem was first formulated by Cooper [4] in 1963. Thereafter several approaches were used for solving these problems. Under crisp environment, various extensions and applications in the area of facility location can be found in $[8,9,26]$.

In 1979, Narasimhan [7], presented an application of fuzzy set theory for locating the gas stations. In 1987, Darzentas [20], formulated a discrete location model with fuzzy accessibility using integer programming. In 1992, Bhattacharya et al. [12] presented a fuzzy goal programming model for locating a single facility on a plane bounded by a convex polygon under the triple criteria maximin, minimax and minisum location. Also, in 1993, Bhattacharya et al. [13] presented a fuzzy goal programming model for locating multiple new facilities on a plane bounded by a convex polygon under the criteria: (1) minimize the sum of all the transportation costs and (2) minimize the maximum distances from the facilities to the demand points. In 2002, Chu [21], presented a fuzzy TOPSIS model for evaluating facility location selection problem where he used fuzzy numbers for representing the ratings of various alternative locations with different subjective attributes. In 2003 , Kahraman et al. [22] used fuzzy group decision making for facility location. In 2005, Gen et al. [23] formulated a Hybrid genetic algorithm for multi time period production / distribution planning so that production and distribution of goods should be accurate and to be delivered to the correct customer at desired time minimizing the system wide cost. In 2006, Lin et al. [24] used multi-objective meta-heuristics for a location routing problem with multiple use of vehicles on the real and simulated data. In his paper, author applied Tabu search and simulated annealing method and compared their results using a new defined procedure. Caballero et al. [14] in 2007 solved a multi-objective location routing problem for slaughterhouses with a meta-heuristic based on Tabu search taking into account certain economic objectives (start-up, maintenance, and transport costs) and social objectives (social rejection by towns on the truck routes, maximum risk as an 
equity criterion, and the negative implications for towns close to the plant). Uno and Katagiri [25] in 2008, solved single and multi-objective defensive location problem on a network with Tabu search algorithm to locate defensive facilities in order to prevent her/his enemies from reaching an important site called 'core'. In 2012, Gupta A. et al. [27] used this concept of Tabu search for solving warehouse problem.

The concept of Tabu search was formulated for combinatorial optimizations by Glover in 1989-90[2-3].Tabu search is a powerful algorithmic approach that has been applied with great success to many difficult combinatorial problems. A particularly nice feature of Tabu Search is that, like all approaches based on local search, it can handle easily the complicating constraints that are typically found in real-life applications. It is thus a really practical approach. Using this concept, one can seek the best global solution for the transportation problems. To use Tabu search the most important thing required is Tabu list, its existence makes this concept an efficient technique to conduct global search instead of applying to a small portion of search space. Important features of Tabu search:

a) In Tabu list there exist forbidden moves which prevent cycling i.e. revisiting the solution examined recently. The procedure is terminated of the solution obtained has already been examined earlier, or if the solution is not improving after certain number of iterations.

b) Tabu list changes when we move to the next solution whether worst or the best.

c) Solution obtained using Tabu search is best out of the various solutions obtained so far.

As, real numbers can be compared using equality, greater than or lesser than notations it is difficult to compare the Fuzzy numbers. In order to compare the fuzzy numbers, ranking methods are used. There are few very commonly used Fuzzy numbers as Trapezoidal Fuzzy Numbers, Triangular Fuzzy numbers, L-R type fuzzy numbers etc. In this paper, we are using Triangular Fuzzy numbers and for the comparison of triangular fuzzy numbers we are using the ranking function. Various ranking functions are used in the papers [28, 29,30].

In this paper, bi-objective hospital site determination problem is studied under fuzzy environment using the concept of Tabu search. For this, we first search the hospital sites near accidental prone areas and then on the basis of that we obtain various optimal solutions with different transportation costs and time in order to minimize the total transportation cost along with the transportation time using triangular fuzzy numbers.

A comparative study of the work done in this paper vs. few of the papers studied for literature review is as below:

Comparative Study in Tabular Form

\begin{tabular}{|l|l|l|l|}
\hline & Fuzzy Component & Method Used & Objectives \\
\hline Present Paper & Triangular Fuzzy Numbers & Tabu Search Algorithm & $\begin{array}{l}\text { Minimize Total Cost and minimize maximum } \\
\text { time taken to reach the hospital site from } \\
\text { accidental prone area }\end{array}$ \\
\hline Lin et. al. [24] & Crisp Data and & $\begin{array}{l}\text { To minimize total cost and work load } \\
\text { imbalance }\end{array}$ \\
\hline $\begin{array}{l}\text { Uno and } \\
\text { Katagiri [25] }\end{array}$ & $\begin{array}{l}\text { Fuzzy Data (membership } \\
\text { functions are used in the } \\
\text { method) }\end{array}$ & $\begin{array}{l}\text { Interactive } \\
\text { satisfying method for } \\
\text { DLP } \\
\text { method }\end{array}$ & $\begin{array}{l}\text { To locate defensive facilities to prevent enemy } \\
\text { from reaching important site }\end{array}$ \\
\hline $\begin{array}{l}\text { Caballero et. al. } \\
\text { [14] }\end{array}$ & Crisp Data & $\begin{array}{l}\text { MOAMP method based } \\
\text { on Tabu Search }\end{array}$ & To minimize economic an social objectives \\
\hline $\begin{array}{l}\text { Bhattacharya et. } \\
\text { al. [12] }\end{array}$ & Fuzzy Data & Goal Programming & $\begin{array}{l}\text { Locating a single facility under triple criteria } \\
\text { maximin, minimax and minisum location. }\end{array}$ \\
\hline $\begin{array}{l}\text { Bhattacharya et. } \\
\text { al. [13] }\end{array}$ & Fuzzy Data & $\begin{array}{l}\text { Goal Programming } \\
\text { and minimize the maximum distances from the } \\
\text { facilities to the demand points. }\end{array}$ \\
\hline
\end{tabular}

The present paper is organized as follows: In Section-2 few basic definitions, arithmetic operations of Triangular Fuzzy numbers and method for comparing fuzzy numbers are reviewed. Section-3 is Mathematical formulation of bi-objective hospital site problem under fuzzy environment. In Section-4 the Proposed Algorithm is given. In Section-5 Numerical example is solved explaining the algorithm. Section- 6 presents the significance of the present study. Sections-7 discusses the result and conclusion and in Section-8 Future Work is discussed.

\section{PRELIMINARIES}

\section{Fuzzy Set}

A fuzzy set is characterized by a membership function mapping element of a domain, space or universe of discourse $X$ to the unit interval $[0,1]$ i.e. $\widetilde{A}=\left\{\left(x, \mu_{\tilde{A}}(x) ; x \in X\right\}\right.$, here 


$$
\mu_{\tilde{A}}(\mathrm{x}): \mathrm{X} \rightarrow[0,1]
$$

is a mapping called the degree of membership function of the fuzzy set $A$ and $\mu_{\tilde{A}}(x)$ is called the membership value of $x \varepsilon$ $X$ in the fuzzy set $A$. These membership grades are often represented by real numbers ranging from [0, 1$]$.

\section{Triangular Fuzzy Numbers}

It is a fuzzy number represented with three points as follows:

$\tilde{A}=\left(a_{1}, a_{2}, a_{3}\right)$, this representation is interpreted as membership functions and holds the following conditions

(i) $a_{1}$ to $a_{2}$ is increasing function.

(ii) $a_{2}$ to $a_{3}$ is decreasing function.

(iii) $a_{1} \leq a_{2} \leq a_{3}$.

$$
\mu_{\tilde{A}}(\mathrm{x})=\left\{\begin{array}{l}
0 \\
\frac{\left(x-a_{1}\right)}{\left(a_{2}-a_{1}\right)} \\
\frac{\left(a_{3}-x\right)}{\left(a_{3}-a_{2}\right)}
\end{array}\right.
$$

0 $x<a_{1}$

$a_{1} \leq x \leq a_{2}$

$a_{2} \leq \mathcal{x} \leq a_{3}$

$x>a_{3}$

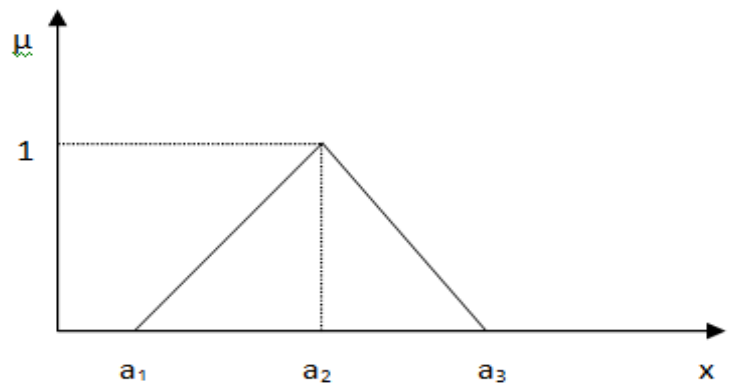

Fig 1. Triangular Fuzzy Number

\section{Properties of Triangular Fuzzy Number}

1) Triangular fuzzy number $\tilde{A}=(a, b, c)$ is said to be non negative triangular fuzzy number Iff $a-c \geq 0$

2) A triangular fuzzy number $\tilde{A}=(a, b, c)$ is said to be zero triangular fuzzy number Iff $a=0, b=0, c=0$.

3) Two triangular fuzzy numbers $\tilde{A} 1=(a 1, b 1, c 1)$ and $\tilde{A} 2=(a 2, b 2, c 2)$ are said to be equal lff $a 1=a 2, b 1=b 2, c 1$ $=\mathrm{c} 2$.

\section{Arithmetic Operators for Solving Triangular Fuzzy Number}

If $\widetilde{\mathrm{A}}=(\mathrm{a} 1, \mathrm{~b} 1, \mathrm{c} 1)$ and $\widetilde{\mathrm{B}}=(\mathrm{a} 2, \mathrm{~b} 2, \mathrm{c} 2)$ two triangular fuzzy numbers then the arithmetic operations on $\widetilde{\mathrm{A}}$ and $\widetilde{\mathrm{B}}$ are as follows:

Addition $\widetilde{\mathrm{A}}+\widetilde{\mathrm{B}}=(\mathrm{a} 1+\mathrm{a} 2, \mathrm{~b} 1+\mathrm{b} 2, \mathrm{c} 1+\mathrm{c} 2)$

Subtraction $\widetilde{A}-\widetilde{B}=(a 1-a 2, b 1-b 2, c 1-c 2)$

\section{Ranking Function}

A ranking function is defined as $R: F(R) \rightarrow R$, where $F(R)$ is set of fuzzy numbers defined on real numbers mapping each fuzzy number to real number.

In 2012, Akyar et. al. [30], gave a convenient method for ranking triangular fuzzy numbers based on their incenter and inradius. To compare triangular fuzzy numbers authors used lexicographical order by their ranks, that is, for triangular fuzzy numbers $\widetilde{A}$ and $\widetilde{B}, \widetilde{A}<\widetilde{B}$ iff $\operatorname{Rank}(\widetilde{A})<L \operatorname{Rank}(\widetilde{B})$, where $<L$ denotes lexicographical order.

A numerical example illustrating their method is as shown below: 
Let $\widetilde{A}=(-0.3,-0.2,0.1)$ and $\widetilde{B}=(0.2,0.3,0.4)$. Using [44], we find

$$
\begin{aligned}
& \mathrm{r}_{\widetilde{\mathrm{A}}}=0.1633, \mathrm{r}_{\widetilde{\mathrm{B}}}=0.0905, \\
& \mathrm{I}_{\widetilde{\mathrm{A}}}=(-.1195,0.1633), \mathrm{I}_{\widetilde{\mathrm{B}}}=(0.3000,0.0905), \\
& \text { and we get }
\end{aligned}
$$

$\operatorname{Rank}(\widetilde{\mathrm{A}})=(-0.2012,0.8367,-0.2)$,

$\operatorname{Rank}(\widetilde{\mathrm{B}})=(0.2548,0.9095,0.3)$.

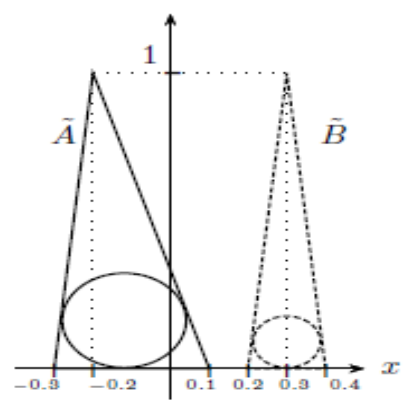

\section{MATHEMATICAL FORMULATION OF BI-OBJECTIVE HOSPITAL SITE PROBLEM UNDER FUZZY ENVIRONMENT}

Let there exist ' $m$ ' accidental prone areas and ' $n$ ' hospital sites and the decision maker wants to select ' $k$ number of sites out of $n$ sites and then wants to gather $m$ accidental sites to the $k$ selected hospital site so as to minimize- total fuzzy cost and maximum fuzzy time required. It is assumed that each site selected for construction of hospital must have at least one accidental prone area attached to it. Mathematically, the above problem may be formulated as

Minimize $\quad \tilde{U}=\sum_{i=1}^{m} \sum_{j=1}^{n} \tilde{c}_{i j} \tilde{x}_{i j}$

Minimize $\tilde{T}$ where $\tilde{T} \cong$ maximum $\left\{\tilde{t}_{i j}: x_{i j}=1, i=1,2, \ldots, m ; j=1,2, \ldots, n\right\}$

Subject to

$$
\begin{array}{ll}
\sum_{j=1}^{n} y_{j} \leq k & \\
\sum_{j=1}^{n} x_{i j}=1 & i=1,2 \ldots, m \\
x_{i j}-y_{j} \leq 0 & i=1,2, \ldots, m ; j=1,2, \ldots, n \\
\sum_{j=1}^{n} \tilde{b}_{j} y_{j} \leq \tilde{B} & \\
x_{i j}, y_{j}=0,1 & i=1,2, \ldots, m ; j=1,2, \ldots, n \\
\sum_{i=1}^{m} x_{i j} \geq y_{j} & j=1,2, \ldots, n
\end{array}
$$

Where

$$
\begin{aligned}
& m=\text { Total number of Accident Prone Areas } \\
& n=\text { Total number of Hospital Sites } \\
& k=\text { Number of Sites to be selected } \\
& \tilde{c}_{i j}=\text { Fuzzy transportation cost from accident prone area to hospital } \\
& \tilde{t}_{i j}=\text { Fuzzy transportation time from accident prone area to hospital } \\
& \tilde{b}_{j}=\text { Fuzzy set up cost for setting up of hospital at } j^{\text {th }} \text { site } \\
& \tilde{B}=\text { Total fuzzy Budgetary amount allocated for setting up of Hospitals. } \\
& X^{l}=\text { The combination of } x_{i j} \text { 's during } t^{\text {th }} \text { non-dominated solution. } \\
& y^{l}=\text { The combination of } y_{j} \text { 's during } t^{\text {th }} \text { non-dominated solution. }
\end{aligned}
$$

$$
\begin{aligned}
x_{i j} & =\left\{\begin{array}{l}
1 \text { if accidental site } i^{\text {th }} \text { is served from } j^{\text {th }} \text { th hospital } \\
0 \text { otherwise }
\end{array}\right. \\
y_{j} & =\left\{\begin{array}{l}
1 \text { if Hospital is established at } j^{\text {th }} \text { site } \\
0 \text { otherwise }
\end{array}\right.
\end{aligned}
$$

\section{PROPOSED ALGORITHM}

Step 1: Let $\tilde{z} \cong \min \left\{\sum_{i=1}^{m} \tilde{c}_{i j}: j=1,2, \ldots, n\right\}$ and $\tilde{T}_{j} \cong \max \left\{\tilde{t}_{i j}: i=1,2, \ldots, m\right\}$ for $j=1,2, \ldots, n$

There are two cases now. 
Case 1: If $\tilde{z}$ occurs corresponding to a unique value of $j$ i.e. $j=t$, where $t \in\{1,2, \ldots, n\}$, then $t$ is the first potential site for the first hospital.

Case 2: If $\tilde{z}$ occurs corresponding to more than one values of $j$ i.e. $j=p_{1}, p_{2}, . ., p_{r}$ then find the $\min \left\{\tilde{T}_{p 1}, \tilde{T}_{p 2}, \ldots, \widetilde{T}_{p r}\right\}$.

Case 2a: If the minimum value is unique corresponding to $p_{l}$, then $p_{l}$ is the first potential site for first hospital.

Case $2 b$ : If the minimum value corresponds to more than one value of $j$, i.e. $j=p_{s 1}, p_{s 2}, \ldots, p_{s q}$, then we can select any $j$ from $p_{s 1}, p_{s 2}, \ldots, p_{s q}$, as the first potential site for the first hospital.

Step 2: Let the first potential site selected for first hospital be $h_{1}$ where $h_{1} \in\{1,2, \ldots, n\}$. Now for choosing the next hospital site, say $h_{2}$, where $h_{2} \neq h_{1}$, we need to construct a new table as shown in Table 1:

Table 1: Bi-Objective Hospital Site Problem

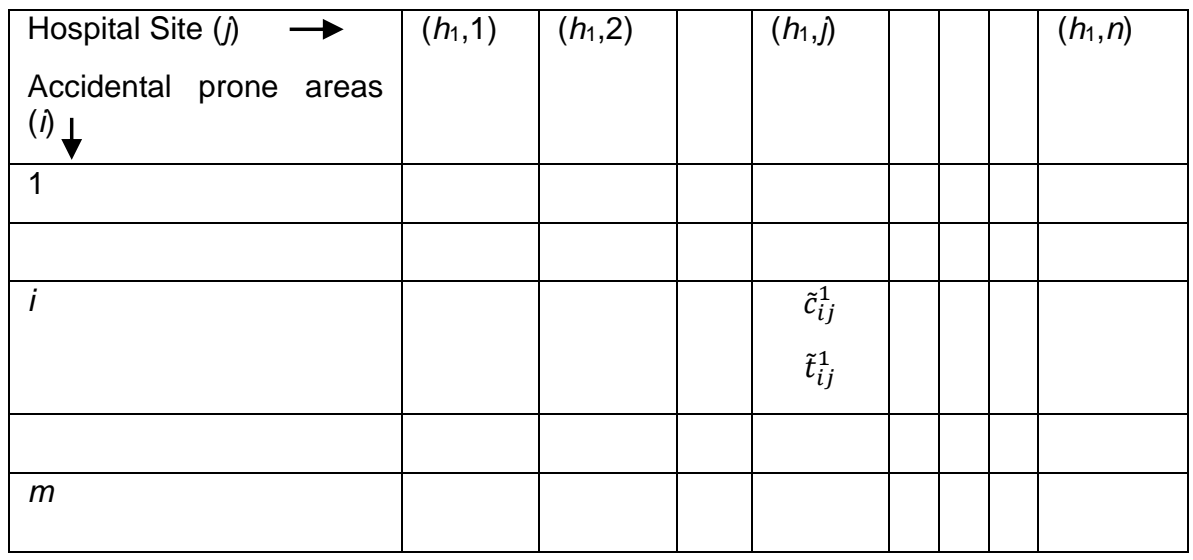

Let the cost and time of $(i, j)^{\text {th }}$ cell, $j \neq h_{1}$ in new table be $\tilde{c}_{i j}^{1}$ and $\tilde{t}_{i j}^{1}$, where

$$
\begin{aligned}
\tilde{c}_{i j}^{1} \cong \min \left\{\tilde{c}_{i h 1}, \tilde{c}_{i j}\right\} \\
\text { And } \quad \tilde{t}_{i j}^{1} \cong\left\{\begin{array}{cc}
\tilde{t}_{i j} & \text { if } \min \left(\tilde{c}_{i h 1}, \tilde{c}_{i j}\right) \cong \tilde{c}_{i j} \\
\tilde{t}_{i h 1} & \text { if } \min \left(\tilde{c}_{i h 1}, \tilde{c}_{i j}\right) \cong \tilde{c}_{i h 1}
\end{array}\right.
\end{aligned}
$$

Now, again applying Step 1, we find new combination of hospital sites, say, $\left(h_{1}, h_{2}\right)$, where

$h_{2} \in\{1,2, \ldots, n\}$ and $h_{2} \neq h_{1}$.

Step 3: Let, $\left(h_{1}, h_{2}\right)$, represent two potential sites for two hospitals. Similarly, using Step 2, find $\mathrm{k}$ potential sites for $\mathrm{k}$ hospitals, say, $\left(h_{1}, h_{2}, \ldots, h_{k}\right)$. This combination yields 0 th iterative solution $\left(X_{0}^{1}, Y_{0}^{1}\right)$ for the first efficient solution $\left(X^{1}, Y^{1}\right)$. After applying various iterations, the optimal solution for the first efficient solution $\left(X^{1}, Y^{1}\right)$ is the best solution obtained.

Step 4: For improving the solution, we use the drop and add rules with Tabu Search, here, the first selected site, i.e. $h_{1}$ is dropped. This site is included in the Tabu list for add and is prohibited from being, selected in next iterative solution $\left(X_{1}^{1}, Y_{1}^{1}\right)$ and $k-1$ left sites $\left(h_{2}, h_{3} \ldots h_{k}\right)$, appearing in the order of their selection in $0^{\text {th }}$ iterative solution are included in Tabu list for drop. Using Steps 1 and 2, find all the entries corresponding to combination $\left(h_{2}, h_{3}, \ldots, h_{k}\right)$ and add the new site,

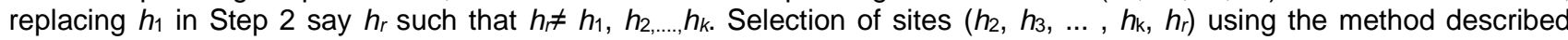
above yields the first iterative solution $\left(X_{1}^{1}, Y_{1}^{1}\right)$ for the first efficient solution $\left(X^{1}, Y^{1}\right)$. Evaluate the cost $\tilde{C}\left(X_{1}^{1}\right)$ and time $\tilde{T}\left(X_{1}^{1}\right)$ for $\left(h_{2}, h_{3}, \ldots, h_{k}, h_{r}\right)$.

If $\tilde{C}\left(X_{1}^{1}\right)<\tilde{C}\left(X_{0}^{1}\right)$ then the current iterative solution is taken as the optimal solution for the next iteration, else there is no change in the optimal solution. Similarly, we derive the second iterative solution $\left(X_{2}^{1}, Y_{2}^{1}\right)$, by changing both the Tabu list and if the second iterative solution $\left(X_{2}^{1}, Y_{2}^{1}\right)$ is better than the optimal solution, then the current iterative solution is taken as the optimal solution for the next iteration, else the optimal solution remains as is. The third iterative solution $\left(X_{3}^{1}, Y_{3}^{1}\right)$, and the successive iterative solutions will be obtained in the similar way as explained for $1^{\text {st }}$ and $2^{\text {nd }}$ iterative solutions.

This iterative process is terminated when,

- $\quad$ Either, we revisit an already visited iterative solution

- Or, there are no sites left that help in improving the solution.

The optimal solution obtained at the end of these iterations, becomes $1^{\text {st }}$ efficient solution $\left(X^{1}, Y^{\uparrow}\right)$. 
Step 5: The $2^{\text {nd }}$ fuzzy efficient solution $\left(X^{2}, Y^{2}\right)$, will be obtained, by replacing $\tilde{t}_{i j}$ 's $\geq \tilde{T}\left(X^{1}\right)$ with arbitrarily large fuzzy number $(M, M, M)$ and thus repeating Step $1-5$. The optimal solution at the end of iterative process gives second fuzzy efficient solution $\left(X^{2}, Y^{2}\right)$. Similarly $3^{\text {rd }}$ and the successive solutions can be obtained.

For $2^{\text {nd }}, 3^{\text {rd }}$ and subsequent fuzzy effective solutions if $\widetilde{T}_{j}$ 's for all the combinations are arbitrarily large fuzzy number ( $M, M$, $M)$, then consider minimum time for the rows instead of the cost factor.

An example of the above situation is shown below in Table 2:

Table 2: Sample Table with Large Fuzzy Dataset

\begin{tabular}{|c|c|c|c|c|}
\hline $\begin{array}{l}\text { Hospital Site }(J) \rightarrow \\
\text { Accidental prone areas } \\
(I) \downarrow\end{array}$ & 1 & 2 & $j$ & $n$ \\
\hline 1 & $\begin{array}{l}\left(a_{1}, b_{1}, C_{1}\right) \\
(M, M, M)\end{array}$ & $\begin{array}{l}\left(a_{2}, b_{2}, c_{2}\right) \\
\left(x_{1}, y_{1}, z_{1}\right)\end{array}$ & $\begin{array}{l}\left(a_{j}, b_{j}, C_{j}\right) \\
(M, M, M)\end{array}$ & $\begin{array}{l}\left(a_{n}, b_{n}, c_{n}\right) \\
\left(x_{n}, y_{n}, z_{n}\right)\end{array}$ \\
\hline 2 & $\begin{array}{l}\left(p_{1}, q_{1}, r_{1}\right) \\
\left(x_{2}, y_{2}, z_{2}\right)\end{array}$ & $\begin{array}{l}\left(p_{2}, q_{2}, r_{2}\right) \\
(M, M, M)\end{array}$ & $\begin{array}{l}\left(p_{j}, q_{j}, r_{j}\right) \\
\left(x_{j}, y_{j}, z_{j}\right)\end{array}$ & $\begin{array}{l}\left(p_{n}, q_{n}, r_{n}\right) \\
(M, M, M)\end{array}$ \\
\hline$i$ & & & $\begin{array}{l}\tilde{c}_{i j}^{1} \\
\tilde{t}_{i j}^{1}\end{array}$ & \\
\hline$m$ & & & & \\
\hline$\tilde{T}_{j}$ & $(M, M, M)$ & $(M, M, M)$ & $(M, M, M)$ & $(M, M, M)$ \\
\hline
\end{tabular}

Since $\tilde{T}_{j}$ 's for all the hospital sites is $(M, M, M)$ and we have to consider combination of sites $(2,1)$ then, for the $1 \mathrm{st}$ accidental prone area $\left[\left(a_{2}, b_{2}, c_{2}\right)\left(x_{1}, y_{1}, z_{1}\right)\right]$ and for $2^{\text {nd }}$ accidental prone area $\left[\left(p_{1}, q_{1}, r_{1}\right)\left(x_{2}, y_{2}, z_{2}\right)\right]$ cost and time factor will be chosen.

Step 6: Process of obtaining the fuzzy efficient solutions is terminated when the algorithm no longer provides a better solution having a lesser time duration than the already existing optimal solution.

\section{Important Remarks}

Salhi (2002) [31] provides three approaches for defining tabu tenure; fixed to a predetermined value, randomly chosen from a specific range, or dynamically changing by adjusting the value. In this work, a predetermined fixed value is examined. Before choosing the fixed value, the experiment of varying tabu tenure should be carried out to choose the best tabu tenure (Peng, 2010) [32]. The experiment involves testing several numbers, tabu tenure is increased when the same solution is visited over and over and is decreased when no duplicate solution have been marked for some time. In this work 10, 5, 3, 20 were tested and the outcomes showed that as the tabu tenure becomes large, it results into driving the search away from the global optimum. To avoid this, the shorter enough is chosen.

\section{NUMERICAL EXAMPLE}

Using the following example we illustrate the proposed algorithm.

Let $m=5, n=7, k=3, \widetilde{B}=(1380,1400,1420)$. Table 3 provides tableau representation of the numerical problem. In the table upper entries of $(i, j)^{t h}$ cell represents the fuzzy cost $\tilde{c}_{i j}$ and the lower entries represents the fuzzy time $\tilde{t}_{i j}$ of transportation, respectively from $i^{\text {th }}$ accidental prone area to potential Hospital site.

Table 3: Numerical Problem

\begin{tabular}{|c|c|c|c|c|c|c|c|}
\hline $\begin{array}{l}\text { Hospital Sites } \\
\rightarrow \\
\text { Accident } \\
\text { Prone Areas } \downarrow\end{array}$ & 1 & 2 & 3 & 4 & 5 & 6 & 7 \\
\hline 1 & $\begin{array}{l}(38,40, \\
42) \\
(5,8,11)\end{array}$ & $\begin{array}{l}(28,30,32) \\
(1,2,3)\end{array}$ & $\begin{array}{l}(44,48,58) \\
(9,11,13)\end{array}$ & $\begin{array}{l}(117,120, \\
123) \\
(4,6,8)\end{array}$ & $\begin{array}{l}(175,177,18 \\
8) \\
(8,10,12)\end{array}$ & $\begin{array}{l}(165,168,17 \\
7) \\
(6,8,13)\end{array}$ & $\begin{array}{l}(143,150,15 \\
6) \\
(5,7,9)\end{array}$ \\
\hline 2 & $\begin{array}{l}(69,70, \\
71)\end{array}$ & $\begin{array}{l}(75,80,85) \\
(4,6,8)\end{array}$ & $\begin{array}{l}(128,130,1 \\
32)\end{array}$ & $\begin{array}{l}(128,130, \\
132)\end{array}$ & $\begin{array}{l}(165,168,17 \\
7)\end{array}$ & $\begin{array}{l}(133,140,14 \\
7)\end{array}$ & $\begin{array}{l}(16,18,26) \\
(9,11,13)\end{array}$ \\
\hline
\end{tabular}




\begin{tabular}{|l|l|l|l|l|l|l|l|}
\hline & $(4,6,8)$ & & $(6,8,13)$ & $(5,7,9)$ & $(5,8,11)$ & $(8,10,12)$ & \\
\hline 3 & $\begin{array}{l}(75,80, \\
85) \\
(5,8,11)\end{array}$ & $\begin{array}{l}(16,18,26) \\
(6,8,13)\end{array}$ & $\begin{array}{l}(188,195,2 \\
10) \\
(3,5,7)\end{array}$ & $\begin{array}{l}(69,70,71) \\
(5,8,11)\end{array}$ & $\begin{array}{l}(133,140,14 \\
7) \\
(9,11,13)\end{array}$ & $\begin{array}{l}(128,130,13 \\
2) \\
(9,11,16)\end{array}$ & $\begin{array}{l}(56,58,66) \\
(8,10,12)\end{array}$ \\
\hline \multirow{4}{*}{4} & $\begin{array}{l}(56,58, \\
66) \\
(9,11,1 \\
3)\end{array}$ & $\begin{array}{l}(7,8,15) \\
(4,6,8)\end{array}$ & $\begin{array}{l}(69,70,71) \\
(9,12,18)\end{array}$ & $\begin{array}{l}(75,80,85) \\
(9,11,13)\end{array}$ & $\begin{array}{l}(28,30,32) \\
(6,8,13)\end{array}$ & $\begin{array}{l}(152,159,16 \\
9) \\
(5,8,11)\end{array}$ & $\begin{array}{l}(195,210,23 \\
0 \\
(4,6,8)\end{array}$ \\
\hline \multirow{3}{*}{5} & $\begin{array}{l}(78,87, \\
105) \\
(8,10,1 \\
2)\end{array}$ & $\begin{array}{l}(90,95,115 \\
(10,13,16)\end{array}$ & $\begin{array}{l}(16,18,26) \\
(5,8,11)\end{array}$ & $\begin{array}{l}(56,58,66) \\
(9,11,16)\end{array}$ & $\begin{array}{l}(38,40,42) \\
(4,6,8)\end{array}$ & $\begin{array}{l}(44,48,58) \\
(3,5,10)\end{array}$ & $\begin{array}{l}(200,220,24 \\
0 \\
(14,16,18)\end{array}$ \\
\hline Set Up Cost & $\begin{array}{l}(90,95, \\
115)\end{array}$ & $\begin{array}{l}(290,300,3 \\
10)\end{array}$ & $\begin{array}{l}(670,700,7 \\
30)\end{array}$ & $\begin{array}{l}(760,790, \\
850)\end{array}$ & $\begin{array}{l}(380,392,42 \\
8)\end{array}$ & $\begin{array}{l}(178,196,21 \\
6)\end{array}$ & $\begin{array}{l}(460,490,55 \\
0)\end{array}$ \\
\hline
\end{tabular}

Table 4 represents the total fuzzy cost $\sum_{i=1}^{5} \tilde{c}_{i j}$ and fuzzy time $\tilde{T}_{j}$ obtained using Step 1.

Table 4: Total Fuzzy Cost and Maximum Fuzzy time for $1^{\text {st }}$ hospital site

\begin{tabular}{|c|l|l|l|l|l|l|l|}
\hline $\begin{array}{l}\text { Hospital } \\
\text { Sites } \rightarrow \\
\text { Accident } \\
\text { Prone } \\
\text { Areas } \downarrow\end{array}$ & 1 & 2 & 3 & 4 & 5 & 6 & 7 \\
\hline$\sum_{i=1}^{5} \tilde{c}_{i j}$ & $(316,335,369$ & $(216,231,273$ & $(445,461,497$ & $(445,458,477$ & $(539,555,586$ & $(622,645,683$ & $(610,651,708$ \\
\hline$\tilde{T}_{j}$ & $(9,11,13)$ & $(10,13,16)$ & $(9,12,18)$ & $(9,11,16)$ & $(9,11,13)$ & $(9,11,16)$ & $(14,16,18)$ \\
\hline
\end{tabular}

Since the minimum value of fuzzy cost corresponds to $j=2$, therefore, $h_{1}=2$, is the first potential site for first hospital site. The various combinations of $2^{\text {nd }}$ site with others are shown in Table 5 using Step 2.

Table 5: Total Fuzzy Cost and Maximum Fuzzy time for two hospital sites

\begin{tabular}{|c|c|c|c|c|c|c|}
\hline $\begin{array}{lr}\text { Hospital } & \text { Sites } \rightarrow \\
\text { Accident } & \text { Prone } \\
\text { Areas } \downarrow & \end{array}$ & $(2,1)$ & $(2,3)$ & $(2,4)$ & $(2,5)$ & $(2,6)$ & $(2,7)$ \\
\hline 1 & $\begin{array}{l}(28,30,32) \\
(1,2,3)\end{array}$ & $\begin{array}{l}(28,30,32) \\
(1,2,3)\end{array}$ & $\begin{array}{l}(28,30,32) \\
(1,2,3)\end{array}$ & $\begin{array}{l}(28,30,32) \\
(1,2,3)\end{array}$ & $\begin{array}{l}(28,30,32) \\
(1,2,3)\end{array}$ & $\begin{array}{l}(28,30,32) \\
(1,2,3)\end{array}$ \\
\hline 2 & $\begin{array}{l}(69,70,71) \\
(4,6,8)\end{array}$ & $\begin{array}{l}(75,80,85) \\
(4,6,8)\end{array}$ & $\begin{array}{l}(75,80,85) \\
(4,6,8)\end{array}$ & $\begin{array}{l}(75,80,85) \\
(4,6,8)\end{array}$ & $\begin{array}{l}(75,80,85) \\
(4,6,8)\end{array}$ & $\begin{array}{l}(16,18,26) \\
(9,11,13)\end{array}$ \\
\hline 3 & $\begin{array}{l}(16,18,26) \\
(6,8,13)\end{array}$ & $\begin{array}{l}(16,18,26) \\
(6,8,13)\end{array}$ & $\begin{array}{l}(16,18,26) \\
(6,8,13)\end{array}$ & $\begin{array}{l}(16,18,26) \\
(6,8,13)\end{array}$ & $\begin{array}{l}(16,18,26) \\
(6,8,13)\end{array}$ & $\begin{array}{l}(16,18,26) \\
(6,8,13)\end{array}$ \\
\hline 4 & $\begin{array}{l}(7,8,15) \\
(4,6,8)\end{array}$ & $\begin{array}{l}(7,8,15) \\
(4,6,8)\end{array}$ & $\begin{array}{l}(7,8,15) \\
(4,6,8)\end{array}$ & $\begin{array}{l}(7,8,15) \\
(4,6,8)\end{array}$ & $\begin{array}{l}(7,8,15) \\
(4,6,8)\end{array}$ & $\begin{array}{l}(7,8,15) \\
(4,6,8)\end{array}$ \\
\hline 5 & $\begin{array}{l}(78,87,105) \\
(8,10,12)\end{array}$ & $\begin{array}{l}(16,18,26) \\
(5,8,11)\end{array}$ & $\begin{array}{l}(56,58,66) \\
(9,11,16)\end{array}$ & $\begin{array}{l}(38,40,42) \\
(4,6,8)\end{array}$ & $\begin{array}{l}(44,48,58) \\
(3,5,10)\end{array}$ & $\begin{array}{l}(90,95,115) \\
(10,13,16)\end{array}$ \\
\hline$\sum_{i=1}^{5} \tilde{c}_{i j}$ & $(198,213,249)$ & $(142,154,184)$ & $(182,194,224)$ & $(164,176,200)$ & $(170,184,209)$ & $(157,169,214)$ \\
\hline$\widetilde{T}_{j}$ & $(8,10,12)$ & $(6,8,13)$ & $(9,11,16)$ & $(6,8,13)$ & $(6,8,13)$ & $(10,13,16)$ \\
\hline
\end{tabular}

Since the minimum value of total fuzzy cost corresponds to $(2,3)$, thus $(2,3)$ are the required two potential sites for the two hospitals. Again using Step 2, we evaluate the third potential site for hospital.

Combination of sites $(2,3,4)$ and $(2,3,7)$ do not satisfy the budgetary constraint $(6)$.

Combination of sites $(2,3,5)$ and $(2,3,6)$ do not satisfy constraint $(8)$. 
Hence the only combination left satisfying all the constraints is $(2,3,1)$, represented in Table 6 .

Table 6: Total Fuzzy Cost and Maximum Fuzzy time for three hospital sites

\begin{tabular}{|c|c|}
\hline $\begin{array}{lr}\text { Hospital } & \text { Sites } \rightarrow \\
\text { Accident } & \text { Prone } \\
\text { Areas } \downarrow & \end{array}$ & $(2,3,1)$ \\
\hline 1 & $\begin{array}{l}(28,30,32) \\
(1,2,3)\end{array}$ \\
\hline 2 & $\begin{array}{l}(69,70,71) \\
(4,6,8)\end{array}$ \\
\hline 3 & $\begin{array}{l}(16,18,26) \\
(6,8,13)\end{array}$ \\
\hline 4 & $\begin{array}{l}(7,8,15) \\
(4,6,8)\end{array}$ \\
\hline 5 & $\begin{array}{l}(16,18,26) \\
(5,8,11)\end{array}$ \\
\hline$\sum_{i=1}^{5} \tilde{c}_{i j}$ & $(136,144,170)$ \\
\hline$\widetilde{\mathrm{T}_{\mathrm{j}}}$ & $(6,8,13)$ \\
\hline
\end{tabular}

Thus, Table 7 represents the current solution obtained for 0th iteration.

Table 7: Current and Optimal Solution for Oth Iteration

\begin{tabular}{|l|c|c|l|l|l|}
\hline \multicolumn{2}{|l|}{ Current Solution $\left(\mathrm{X}_{0}^{1}, \mathrm{Y}_{0}^{1}\right)$} & \multicolumn{3}{l|}{ Optimal Solution $\left(\mathrm{X}_{0}^{1}, \mathrm{Y}_{0}^{1}\right)$} \\
\hline Variables $x_{i j}, y_{i j}$ & $\tilde{C}\left(X_{0}^{1}\right)$ & $\tilde{T}\left(X_{0}^{1}\right)$ & Variables $x_{i j}, y_{i j}$ & $\tilde{C}\left(X_{0}^{1}\right)$ & $\tilde{T}\left(X_{0}^{1}\right)$ \\
\hline$y_{2}, y_{3}, y_{1}$ & $(136,144,170)$ & $(6,8,13)$ & $y_{2}, y_{3}, y_{1}$ & $(136,144,170)$ & $(6,8,13)$ \\
$x_{12}, x_{21}, x_{32}, x_{42}$, & & & $x_{12}, x_{21}, x_{32}, x_{42}$, & & \\
$x_{53}$ & & $x_{53}$ & & \\
\hline
\end{tabular}

\section{$1^{\text {st }}$ Iteration:}

As the combination of hospital sites in $0^{\text {th }}$ iteration is $(2,3,1)$, thus we obtain, two Tabu lists given in Table 8 .

Table 8: Two Tabu Lists for $1^{\text {st }}$ Iteration

\begin{tabular}{|l|l|}
\hline Tabu List for Drop & Tabu List for Add \\
\hline$\left\{y_{3}, y_{1}\right\}$ & $\left\{y_{2}\right\}$ \\
\hline
\end{tabular}

Using Step 2, we establish the new combinations with $(3,1)$ as $(3,1,4),(3,1,5),(3,1,6)$ and $(3,1,7)$. Combination of sites $(3,1,4)$ do not satisfy constraint $(6)$ and $(3,1,6)$ do not satisfy constraint $(8)$. Combinations $(3,1,5)$ and $(3,1,7)$ satisfy all the constraints as shown in Table 9.

Table 9: Total Fuzzy Cost and Maximum Fuzzy time for $1^{\text {st }}$ Iteration

\begin{tabular}{|l|l|l|}
\hline $\begin{array}{l}\text { Hospital Sites } \\
\text { Accident Prone Areas } \downarrow\end{array}$ & $(3,1,5)$ & $(3,1,7)$ \\
\hline 1 & $\begin{array}{l}(38,40,42) \\
(5,8,11)\end{array}$ & $\begin{array}{l}(38,40,42) \\
(5,8,11)\end{array}$ \\
\hline 2 & $\begin{array}{l}(69,70,71) \\
(4,6,8)\end{array}$ & $\begin{array}{l}(16,18,26) \\
(9,11,13)\end{array}$ \\
\hline 3 & $\begin{array}{l}(75,80,85) \\
(5,8,11)\end{array}$ & $\begin{array}{l}(56,58,66) \\
(8,10,12)\end{array}$ \\
\hline 4 & $\begin{array}{l}(28,30,32) \\
(6,8,13)\end{array}$ & $\begin{array}{l}(56,58,66) \\
(9,11,13))\end{array}$ \\
\hline 5 & $\begin{array}{l}(16,18,26) \\
(5,8,11)\end{array}$ & $\begin{array}{l}(16,18,26) \\
(5,8,11)\end{array}$ \\
\hline
\end{tabular}




\begin{tabular}{|c|l|l|}
\hline$\sum_{i=1}^{5} \tilde{c}_{i j}$ & $(226,238,256)$ & $(182,192,226)$ \\
\hline$\tilde{T}_{j}$ & $(6,8,13)$ & $(9,11,13)$ \\
\hline
\end{tabular}

From above table, $\tilde{C}\left(X_{I}^{I}\right)=(182,192,226)$ is greater than the total fuzzy optimal cost from $0^{\text {th }}$ iteration $\tilde{C}\left(X_{0}^{I}\right)$. Thus the optimal solution remains the same as shown in Table 10.

Table 10: Current and Optimal solution for $1^{\text {st }}$ Iteration

\begin{tabular}{|l|c|c|l|l|l|}
\hline \multicolumn{2}{|l|}{ Current Solution $\left(X_{1}^{1}, Y_{1}^{1}\right)$} & \multicolumn{3}{l|}{ Optimal Solution $\left(X_{0}^{1}, Y_{0}^{1}\right)$} \\
\hline Variables $x_{i j}, y_{i j}$ & $\tilde{C}\left(X_{1}^{1}\right)$ & $\tilde{T}\left(X_{1}^{1}\right)$ & \multicolumn{1}{|c|}{ Variables $x_{i j}, y_{i j}$} & $\tilde{C}\left(X_{0}^{1}\right)$ & \\
\hline$Y_{3}, y_{1}, y_{7}$ & $(182,192,226)$ & $(9,11,13)$ & $y_{2}, y_{3}, y_{1}$ & $(136,144,170)$ & $(6,8,13)$ \\
$x_{11}, x_{27}, x_{37}, x_{41}$, & & & $x_{12}, x_{21}, x_{32}, x_{42}$, & & \\
$x_{53}$ & & $x_{53}$ & & \\
\hline
\end{tabular}

\section{$2^{\text {nd }}$ Iteration:}

As the combination of hospital sites in $1^{\text {st }}$ iteration is $(3,1,7)$, thus we obtain, two Tabu lists given in Table 11 .

Table 11: Two Tabu Lists for $2^{\text {nd }}$ Iteration

\begin{tabular}{|l|l|}
\hline Tabu List for Drop & Tabu List for Add \\
\hline$\left\{y_{1}, y_{7}\right\}$ & $\left\{y_{3}\right\}$ \\
\hline
\end{tabular}

Proceeding as in above iteration we obtain the results up to $6^{\text {th }}$ iteration. After $6^{\text {th }}$ iteration the result revisits the $2^{\text {nd }}$ iteration solution. Results of all iterations are shown in Table 12.

Table 12: Iterative Solutions for $1^{\text {st }}$ Non Dominated Fuzzy Efficient Solution

\begin{tabular}{|c|c|c|c|c|c|c|}
\hline $\begin{array}{l}\text { Iterative } \\
\text { Solutions }\end{array}$ & $\begin{array}{l}\text { Variables } x_{i j} \text { 's and } y_{j}^{\prime} \text { s in the } \\
\text { order of appearance }\end{array}$ & $\begin{array}{ll}\text { Total } & \text { Fuzzy } \\
\text { Cost } \tilde{C}\left(X_{r}^{1}\right) & \end{array}$ & $\begin{array}{l}\text { Fuzzy } \\
\text { Time } \tilde{T}\left(X_{r}^{1}\right)\end{array}$ & $\begin{array}{l}\text { Tabu List } \\
\text { for Drop }\end{array}$ & $\begin{array}{l}\text { Tabu List } \\
\text { for Add }\end{array}$ & $\begin{array}{l}\text { Optimal } \\
\text { solution }\end{array}$ \\
\hline$\left(X_{0}^{1}, Y_{0}^{1}\right)$ & $\begin{array}{l}x_{12}, x_{21}, x_{32}, x_{42}, x_{53} \\
y_{2,} y_{3}, y_{1}\end{array}$ & $(136,144,170)$ & $(6,8,13)$ & $\left\{y_{3}, y_{1}\right\}$ & $\left\{y_{2}\right\}$ & $\left(X_{0}^{1}, Y_{0}^{1}\right)$ \\
\hline$X_{1}^{1}, Y_{1}^{1}$ & $\begin{array}{l}x_{11}, x_{27}, x_{37}, x_{42}, x_{53} \\
y_{3,} y_{1}, y_{7}\end{array}$ & $(182,192,226)$ & $(9,11,13)$ & $\left\{y_{1}, y_{7}\right\}$ & $\left\{y_{3}\right\}$ & $\left(X_{0}^{1}, Y_{0}^{1}\right)$ \\
\hline$X_{2}^{1}, Y_{2}^{1}$ & $\begin{array}{l}x_{12}, x_{27}, x_{32}, x_{42}, x_{51} \\
y_{1,} y_{7}, y_{2}\end{array}$ & $(145,261,204)$ & $(9,11,13)$ & $\left\{y_{7}, y_{2}\right\}$ & $\left\{y_{1}\right\}$ & $\left(X_{0}^{1}, Y_{0}^{1}\right)$ \\
\hline$X_{3}^{1}, Y_{3}^{1}$ & $\begin{array}{l}x_{12}, x_{27}, x_{32}, x_{42}, x_{55} \\
y_{7,} y_{2}, y_{5}\end{array}$ & $(105,114,141)$ & $(9,11,13)$ & $\left\{y_{2}, y_{5}\right\}$ & $\left\{y_{7}\right\}$ & $\left(X_{3}^{1}, Y_{3}^{1}\right)$ \\
\hline$X_{4}^{1}, Y_{4}^{1}$ & $\begin{array}{l}x_{12}, x_{21}, x_{32}, x_{42}, x_{55} \\
y_{2,} y_{5}, y_{1}\end{array}$ & $(158,166,186)$ & $(6,8,13)$ & $\left\{y_{5}, y_{1}\right\}$ & $\left\{y_{2}\right\}$ & $\left(X_{3}^{1}, Y_{3}^{1}\right)$ \\
\hline$X_{5}^{1}, Y_{5}^{1}$ & $\begin{array}{l}x_{11}, x_{27}, x_{37}, x_{45}, x_{55} \\
y_{5,} y_{1}, y_{7}\end{array}$ & $(176,186,208)$ & $(9,11,13)$ & $\left\{y_{1}, y_{7}\right\}$ & $\left\{y_{5}\right\}$ & $\left(X_{3}^{1}, Y_{3}^{1}\right)$ \\
\hline$X_{6}^{1}, Y_{6}^{1}$ & $\begin{array}{l}x_{12}, x_{27}, x_{32}, x_{42}, x_{51} \\
y_{1,} y_{7}, y_{2}\end{array}$ & $(145,261,204)$ & $(9,11,13)$ & $\left\{y_{7}, y_{2}\right\}$ & $\left\{y_{1}\right\}$ & $\left(X_{3}^{1}, Y_{3}^{1}\right)$ \\
\hline
\end{tabular}

The Iteration procedure terminates at $6^{\text {th }}$ iteration as the $2^{\text {nd }}$ iteration result is repeated at $6^{\text {th }}$ iteration.

\section{$2^{\text {nd }}$ NON-DOMINATED FUZZY EFFICIENT SOLUTION:}

As $\tilde{T}_{j}$ for the $1^{\text {st }}$ non-dominated fuzzy efficient solution is $(9,11,13)$, therefore we replace all $\tilde{t}_{i j}$ 's $\geq(9,11,13)$ by arbitrary large fuzzy number $(M, M, M)$ as shown in Table 13 . 
Table 13: Tableau Representation of Numerical Problem for $2^{\text {nd }}$ Non Dominated Solution.

\begin{tabular}{|c|c|c|c|c|c|c|c|}
\hline $\begin{array}{l}\text { Hospital } \\
\text { Sites } \rightarrow \\
\text { Accident } \\
\text { Prone } \\
\text { Areas } \downarrow\end{array}$ & 1 & 2 & 3 & 4 & 5 & 6 & 7 \\
\hline 1 & $\begin{array}{l}(38,40,42) \\
(5,8,11)\end{array}$ & $\begin{array}{l}(28,30,32) \\
(1,2,3)\end{array}$ & $\begin{array}{l}(44,48,58) \\
(\mathrm{M}, \mathrm{M}, \mathrm{M})\end{array}$ & $\begin{array}{l}(117,120,123 \\
(4,6,8)\end{array}$ & $\begin{array}{l}(175,177,188 \\
) \\
(8,10,12)\end{array}$ & $\begin{array}{l}(165,168,177 \\
) \\
(6,8,13)\end{array}$ & $\begin{array}{l}(143,150,156 \\
) \\
(5,7,9)\end{array}$ \\
\hline 2 & $\begin{array}{l}(69,70,71) \\
(4,6,8)\end{array}$ & $\begin{array}{l}(75,80,85) \\
(4,6,8)\end{array}$ & $\begin{array}{l}(128,130,132 \\
) \\
(6,8,13)\end{array}$ & $\begin{array}{l}(128,130,132 \\
) \\
(5,7,9)\end{array}$ & $\begin{array}{l}(165,168,177 \\
(5,8,11)\end{array}$ & $\begin{array}{l}(133,140,147 \\
) \\
(8,10,12)\end{array}$ & $\begin{array}{l}(16,18,26) \\
(M, M, M)\end{array}$ \\
\hline 3 & $\begin{array}{l}(75,80,85) \\
(5,8,11)\end{array}$ & $\begin{array}{l}(16,18,26) \\
(6,8,13)\end{array}$ & $\begin{array}{l}(188,195,210 \\
(3,5,7)\end{array}$ & $\begin{array}{l}(69,70,71) \\
(5,8,11)\end{array}$ & $\begin{array}{l}(133,140,147 \\
(M, M, M)\end{array}$ & $\begin{array}{l}(128,130,132 \\
) \\
(M, M, M)\end{array}$ & $\begin{array}{l}(56,58,66) \\
(8,10,12)\end{array}$ \\
\hline 4 & $\begin{array}{l}(56,58,66) \\
(M, M, M)\end{array}$ & $\begin{array}{l}(7,8,15) \\
(4,6,8)\end{array}$ & $\begin{array}{l}(69,70,71) \\
(\mathrm{M}, \mathrm{M}, \mathrm{M})\end{array}$ & $\begin{array}{l}(75,80,85) \\
(\mathrm{M}, \mathrm{M}, \mathrm{M})\end{array}$ & $\begin{array}{l}(28,30,32) \\
(6,8,13)\end{array}$ & $\begin{array}{l}(152,159,169 \\
) \\
(5,8,11)\end{array}$ & $\begin{array}{l}(195,210,230 \\
) \\
(4,6,8)\end{array}$ \\
\hline 5 & $\begin{array}{l}(78,87,105 \\
) \\
(8,10,12)\end{array}$ & $\begin{array}{l}(90,95,115) \\
(M, M, M)\end{array}$ & $\begin{array}{l}(16,18,26) \\
(5,8,11)\end{array}$ & $\begin{array}{l}(56,58,66) \\
(\mathrm{M}, \mathrm{M}, \mathrm{M})\end{array}$ & $\begin{array}{l}(38,40,42) \\
(4,6,8)\end{array}$ & $\begin{array}{l}(44,48,58) \\
(3,5,10)\end{array}$ & $\begin{array}{l}(200,220,240 \\
) \\
(M, M, M)\end{array}$ \\
\hline $\begin{array}{ll}\text { Set } & \text { Up } \\
\text { Cost } & \end{array}$ & )$^{(90,95,115}$ & )$^{(290,300,310}$ & (670,700,730 & $\begin{array}{l}(760,790,850 \\
\end{array}$ & (380,392,428 & )$^{(178,196,216}$ & )$^{(460,490,550}$ \\
\hline
\end{tabular}

After applying the iterations as done for the $1^{\text {st }}$ Non Dominated Fuzzy efficient solution, the $2^{\text {nd }}$ Non Dominated fuzzy efficient solution obtained is shown below in Table 14.

Table 14: $2^{\text {nd }}$ Non Dominated Fuzzy Efficient Solution

\begin{tabular}{|l|l|l|l|}
\hline 2nd Efficient Solution & Variables $x_{i j}^{\prime}$ 's and $y_{j}^{\prime}$ s & Total Fuzzy Cost $\tilde{C}\left(X^{2}\right)$ & Total Fuzzy Time $\tilde{T}\left(X^{2}\right)$ \\
\hline$\left(X^{2}, Y^{2}\right)$ & $\begin{array}{l}X_{12}, X_{21}, X_{32}, X_{42}, X_{53} \\
y_{2}, y_{3}, y_{1}\end{array}$ & $(136,144,170)$ & $(6,8,13)$ \\
\hline
\end{tabular}

\section{$3^{\text {rd }}$ NON-DOMINATED FUZZY EFFICIENT SOLUTION:}

Proceeding in the similar way as in $2^{\text {nd }}$ Non Dominated fuzzy efficient solution, we replace all $\tilde{t}_{i j}$ 's $\geq(6,8,13)$ by arbitrary large fuzzy number $(M, M, M)$ as shown in Table 15.

Table 15: Tableau Representation of Numerical Problem for $3^{\text {rd }}$ Non Dominated Solution

\begin{tabular}{|c|c|c|c|c|c|c|c|}
\hline $\begin{array}{l}\text { Hospital } \\
\text { Sites } \rightarrow \\
\text { Accident } \\
\text { Prone } \\
\text { Areas } \downarrow\end{array}$ & 1 & 2 & 3 & 4 & 5 & 6 & 7 \\
\hline 1 & $\begin{array}{l}(38,40,42) \\
(5,8,11)\end{array}$ & $\begin{array}{l}(28,30,32) \\
(1,2,3)\end{array}$ & $\begin{array}{l}(44,48,58) \\
(M, M, M)\end{array}$ & $\begin{array}{l}(117,120,123 \\
(4,6,8)\end{array}$ & $\begin{array}{l}(175,177,188 \\
) \\
(M, M, M)\end{array}$ & $\begin{array}{l}(165,168,177 \\
(M, M, M)\end{array}$ & $\begin{array}{l}(143,150,156) \\
(5,7,9)\end{array}$ \\
\hline 2 & $\begin{array}{l}(69,70,71) \\
(4,6,8)\end{array}$ & $\begin{array}{l}(75,80,85) \\
(4,6,8)\end{array}$ & $\begin{array}{l}(128,130,132 \\
(M, M, M)\end{array}$ & $\begin{array}{l}(128,130,132 \\
(5,7,9)\end{array}$ & $\begin{array}{l}(165,168,177 \\
(5,8,11)\end{array}$ & $\begin{array}{l}(133,140,147 \\
(M, M, M)\end{array}$ & $\begin{array}{l}(16,18,26) \\
(M, M, M)\end{array}$ \\
\hline 3 & $\begin{array}{l}(75,80,85) \\
(5,8,11)\end{array}$ & $\begin{array}{l}(16,18,26) \\
(\mathrm{M}, \mathrm{M}, \mathrm{M})\end{array}$ & $\begin{array}{l}(188,195,210 \\
) \\
(3,5,7)\end{array}$ & $\begin{array}{l}(69,70,71) \\
(5,8,11)\end{array}$ & $\begin{array}{l}(133,140,147 \\
) \\
(M, M, M)\end{array}$ & $\begin{array}{l}(128,130,132 \\
(M, M, M)\end{array}$ & $\begin{array}{l}(56,58,66) \\
(M, M, M)\end{array}$ \\
\hline 4 & $\begin{array}{l}(56,58,66) \\
(M, M, M)\end{array}$ & $\begin{array}{l}(7,8,15) \\
(4,6,8)\end{array}$ & $\begin{array}{l}(69,70,71) \\
(M, M, M)\end{array}$ & $\begin{array}{l}(75,80,85) \\
(M, M, M)\end{array}$ & $\begin{array}{l}(28,30,32) \\
(M, M, M)\end{array}$ & $\begin{array}{l}(152,159,169 \\
(5,8,11)\end{array}$ & $\begin{array}{l}(195,210,230) \\
(4,6,8)\end{array}$ \\
\hline 5 & $(78,87,105$ & $\begin{array}{l}(90,95,115) \\
(M, M, M)\end{array}$ & $\begin{array}{l}(16,18,26) \\
(5,8,11)\end{array}$ & $\begin{array}{l}(56,58,66) \\
(M, M, M)\end{array}$ & $\begin{array}{l}(38,40,42) \\
(4,6,8)\end{array}$ & $\begin{array}{l}(44,48,58) \\
(3,5,10)\end{array}$ & $\begin{array}{l}(200,220,240) \\
(M, M, M)\end{array}$ \\
\hline
\end{tabular}




\begin{tabular}{|l|l|l|l|l|l|l|l|} 
& \multicolumn{1}{|l|}{$(M, M, M)$} & & & & & \\
\hline $\begin{array}{l}\text { Set Up } \\
\text { Cost }\end{array}$ & $(90,95,115$ & $(290,300,310$ & $(670,700,730$ & $(760,790,850$ & $(380,392,428$ & )$^{(178,196,216}$ & $(460,490,550)$ \\
\hline
\end{tabular}

After applying the iterations, the $3^{\text {rd }}$ Non Dominated Fuzzy efficient solution obtained is shown below in Table 16.

Table 16: $3^{\text {rd }}$ Non Dominated Fuzzy Efficient Solution

\begin{tabular}{|l|l|l|l|}
\hline 3rd Efficient Solution & Variables $x_{i j}^{\prime}$ 's and $y_{j}^{\prime}$ s & Total Fuzzy Cost $\tilde{C}\left(X^{3}\right)$ & Total Fuzzy Time $\tilde{T}\left(X^{3}\right)$ \\
\hline$\left(X^{3}, Y^{3}\right)$ & $\begin{array}{l}X_{12}, X_{21}, X_{31}, X_{42}, X_{53} \\
y_{2,} y_{3}, y_{1}\end{array}$ & $(195,206,229)$ & $(5,8,11)$ \\
\hline
\end{tabular}

The $4^{\text {th }}$ Non Dominated Fuzzy efficient solution shows no improvement in fuzzy time. Therefore, the procedure of finding fuzzy efficient solution terminates. All fuzzy efficient solutions are given in Table 17.

Table 17: All Efficient Solutions of the Numerical Problem

\begin{tabular}{|c|c|c|c|}
\hline Efficient Solution & Variables $x_{i j}^{\prime}$ s and $y_{j}^{\prime}$ s & Total Fuzzy Cost & Total Fuzzy Time \\
\hline$\left(X^{1}, Y^{1}\right)$ & $\begin{array}{l}x_{12}, x_{27}, x_{32}, x_{42}, x_{55} \\
y_{7,} y_{2}, y_{5}\end{array}$ & $(105,114,141)$ & $(9,11,13)$ \\
\hline$\left(X^{2}, Y^{2}\right)$ & $\begin{array}{l}x_{12}, x_{21}, x_{32}, x_{42}, x_{53} \\
y_{2,} y_{3}, y_{1}\end{array}$ & $(136,144,170)$ & $(6,8,13)$ \\
\hline$\left(X^{3}, Y^{3}\right)$ & $\begin{array}{l}x_{12}, x_{21}, x_{31}, x_{42}, x_{53} \\
y_{2,} y_{3}, y_{1}\end{array}$ & $(195,206,229)$ & $(5,8,11)$ \\
\hline
\end{tabular}

\section{SIGNIFICANCE OF THE PRESENT STUDY}

1) As the hospital sites are often planned intuitively in real life, the government agencies can better plan the location of the hospital sites using the above algorithm especially around the accidental prone areas or along the routes where hazardous material is transported, etc.

2) The solution obtained using the proposed Tabu search algorithm is very close to optimality and is among the most effective to tackle the difficult real life problems at hand. Moreover, the optimal solution obtained is fuzzy in nature, which is more realistic.

3) The algorithm does not require any deep knowledge and understanding of complex concepts like linear programming or goal and parametric programming, etc

\section{CONCLUSION}

Using the traditional approaches, we obtain a single optimal solution. Howsoever, with the help of the above algorithm and the numerical example, we can easily see that we get three efficient solutions using Tabu search algorithm. Thus clearly, using Tabu search algorithm provided above, we get more choices for decision making as shown below in Table 18. Of the below listed solutions, obtained with the above numerical problem, if we observe, the total transportation cost increases from top to bottom, whereas, the total transportation time decreases. As a decision maker to choose a hospital site near an accidental area, we would choose the one listed in the last row as the most suitable solution, as for choosing a hospital site, the most important parameter would be the minimum transportation time rather than the transportation cost involved.

Table 18: Optimal Solutions using Tabu Search

\begin{tabular}{|l|l|l|}
\hline \multicolumn{3}{|c|}{ Optimal Solutions obtained using Tabu algorithm } \\
\hline Variables $\mathrm{x}_{\mathrm{ij}}, \mathrm{y}_{\mathrm{j}}$ & Total Fuzzy Cost $\tilde{\mathrm{C}}$ & Total Fuzzy Time $\widetilde{T}$ \\
\hline $\begin{array}{l}\mathrm{x} 12, \mathrm{x} 27, \mathrm{x} 32, \mathrm{x} 42, \mathrm{x} 55 \\
\mathrm{y} 7, \mathrm{y} 2, \mathrm{y} 5\end{array}$ & $(105,114,141)$ & $(9,11,13)$ \\
\hline $\begin{array}{l}\mathrm{x} 12, \mathrm{x} 21, \mathrm{x} 32, \mathrm{x} 42, \mathrm{x} 53 \\
\mathrm{y} 2, \mathrm{y3}, \mathrm{y} 1\end{array}$ & $(136,144,170)$ & $(6,8,13)$ \\
\hline$x_{12}, x_{21}, x_{31}, x_{42}, x_{53}$ & $(195,206,229)$ & $(5,8,11)$ \\
\hline
\end{tabular}




\section{FUTURE WORK}

1) The present paper has been solved using a sample numerical problem due to limitation of time and process involved in getting the data from government agencies. In future, the numerical problem discussed can be extended to a real life problem, by gathering the required data from concerned agencies.

2) The present paper has solved the algorithm using sample hypothetical data. Though the performance of the algorithm was found to be satisfactory, but it needs to be validated using the real life example data. In future, the algorithm would be validated in terms of solution quality, computation time, sensitivity to parameter setting and problem characteristics, etc., using the real life example data.

3) Instead of triangular fuzzy numbers; intuistic fuzzy numbers or LR type fuzzy numbers can be used to solve the numerical problem.

\section{REFERENCES}

i. $\quad$ Bellman, R. E. and Zadeh, L. A. 1970. Decision making in a fuzzy environment. Management Science. 17(4), $141-64$.

ii. Glover, F. 1989. Tabu search-part I. ORSA Journal on Computing, 1(3), 190-206.

iii. Glover, F. 1990. Tabu search-part II. ORSA Journal on Computing, 2(1), 4-32.

iv. Cooper, L. 1963. Location-allocation problems. Operations Research, 11(3), 331-343.

v. Zadeh, L. A. 1965. Fuzzy sets. Information and Control, 8(3), 338-353.

vi. Dubois, D. and Parade, H. 1980. Fuzzy Sets and Systems, Academic Press, New York.

vii. Narasimhan, R. 1979. A fuzzy subset characterization of a site-selection problem. Decision Sciences, 10(4), 618-628.

viii. Melo, M. T., Nickel, S. and Saldanha-da-Gama, F. 2009. Facility location and supply chain management-a review. European Journal of Operational Research, 196(2), 401-412.

ix. Farahani, R. Z., SteadieSei, M. And Asgari, N. 2010. Multiple criteria facility location problems: a survey. Applied Mathematical Modelling, 34(7), 1689-1709.

x. Sakawa, M. 1993. Fuzzy sets and interactive multiobjective optimization. Plenum Press, New York.

xi. Jaeggi, D.M., Parks, G.T., Kipouros, T. and Clarkson, P.J. 2008. The development of a multiobjective Tabu search algorithm for continuous optimisation problems. Eur. J. Oper. Res. 185, 1192-1212.

xii. Bhattacharya, U., Rao, J. R. and Tiwari, R. N. 1992. Fuzzy multi-criteria facility location problem. Fuzzy Sets and Systems, 51(3), 277-287.

xiii. Bhattacharya, U., Rao, J. R. and Tiwari, R. N. 1993. Bi-criteria multi facility location problem in Fuzzy environment. Fuzzy Sets and Systems, 56(2), 145-153.

xiv. Caballero,R., Gonzalez, M., Guerrero, F. M., Molina, J. and Paralera, C. 2007. Solving a multiobjective location routing problem with a metaheuristic based on Tabu search: application to a real case in Andalusia. European Journal of Operational Research, 177(3), 1751-1763.

xv. Zimmermann, H. J. 1983. Using Fuzzy Sets in Operational Research. European Journal of Operational Research 13.

xvi. Battiti, R. and Tecchiolli, G. 1994. The reactive Tabu search. ORSA J. Comput. 6, 126-140.

xvii. Battiti, R. and Tecchiolli, G. 1996. The continuous reactive Tabu search: blending combinatorial optimization and stochastic search for global optimization. Ann. Oper. Res. 63, 151-188.

xviii. Crainic, T.G., Gendreau, M., Rousseau, L.M. 2010. Special issuse on Recent advances in metaheuristics. J. Heuristics 16(3), 235-535.

xix. Joshi, N. and Chauhan, S. S. 2013. Solution of Fuzzy Transportation Problem using Improved VAM with Roubast Ranking Technique. International Journal of Computer Applications Volume 8, No. 15.

xx. Darzentas, J. 1987. A discrete location model with fuzzy accessibility measures. Fuzzy Sets and Systems, 23(1), 149154.

xxi. Chu, T. C. 2002. Facility location selection using fuzzy TOPSIS under group decisions. International Journal of Uncertainty, Fuzziness and Knowledge-Based Systems, 10(6), 687-702.

xxii. Kahraman, C., Ruan, D. and Dogan, I. 2003. Fuzzy group decision-making for facility location selection. Information Sciences, 157, 135-153.

xxiii. Gen, M. and Syarif, A. 2005. Hybrid genetic algorithm for multi-time period production/ distribution planning.Computers and Industrial Engineering, 48(4), 799-809. 
xxiv. Lin, C. K. Y. and Kwok, R. C. W. 2006. Multi-objective metaheuristics for a location-routing Problem with multiple use of vehicles on real data and simulated data. European Journal of Operational Research, 175(3), 1833-1849.

xxv. Uno, T. and Katagiri, H. 2008. Single and multi-objective defensive location problems on a network. European Journal of Operational Research, 188(1), 76-84.

xxvi. Hale, T. S. and Moberg, C. R. 2003. Location science research: a review.Annals of Operations Research, 123(1-4), 21-35.

xxvii. Gupta, A., Kumar, A. and Sharma, M. K. 2012. An algorithm for solving the bi- objective warehouse problem in a fuzzy environment using tabu search, Iranian Journal of Fuzzy Systems,9(1), 1-19.

xxviii. Bortolan, G. and Degani, R. 1985. A review of some methods for ranking fuzzy subsets. Fuzzy Sets and Systems, Vol. 15, 1-19.

xxix. Li., D. F. 2010. A ratio ranking method of triangular intuitionistic fuzzy numbers and its application to madm problems. Computer and Mathematics with Applications, 60, 1557-1570.

xxx. Akyar, E., Akyar, H. and Duzce, S. A. 2012. A new method for ranking triangular fuzzy numbers. International Journal of Uncertainty, Fuzziness and Knowledge-based systems, Vol 20 (5), 729-740.

xxxi. Salhi, S. 2002. Defining Tabu List Size and Aspiration Criterion with Tabu Search Methods. Computer and Operational Research 29: pp 67-86.

xxxii. Peng, Zebo. 2010. Tabu Search - Basic Principle and Algorithm. Lecture Note Linköping University.

xxxiii. Zitzler, E., Thiele, L., Laumanns, M., Fonseca, C.M., Grunert da Fonseca, V. 2003. Performance assessment of multiobjective optimizers: An analysis and review. IEEE Transactions on Evolutionary Computation 7(2) 117-132.

xxxiv. Fonseca, C.M., Knowles, J., Thiele, L., Zitzler, E. 2005. A tutorial on the performance assessment of stochastic multiobjective optimizers. An invited talk presented by J. Knowles at EMO 2005, Guanajuato, Mexico.

xxxv. Deb, K. 2001. Multi-objective Optimization using Evolutionary Algorithms. John Wiley, Chichester

\section{Author' biography with Photo}

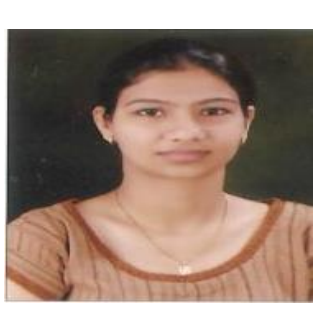

Ms. Nidhi Joshi is a Ph.D research scholar under the supervision of Dr. Surjeet Singh Chauhan (Gonder). She has completed her M.Sc (Mathematics) from Punjab University, Chandigarh, India. Her area of research is Fuzzy Transportation.

Punjab Technical University, Jalandhar (Punjab), India.

e-mail: nids_22@yahoo.co.in

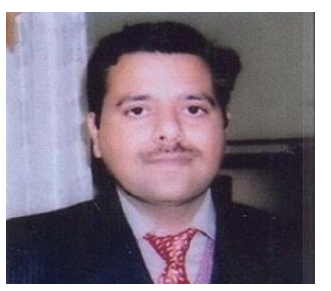

Dr. Surjeet Singh Chauhan(Gonder) (Prof.) is Head of Department in Applied Sciences Department, Chandigarh Group of Colleges, Gharuan, Mohali (Punjab), India. His current area of research is Fuzzy Optimization.

Applied Sciences Department, Chandigarh Group of Colleges, Gharuan, Mohali (Punjab), India. e-mail: surjeetschauhan@yahoo.com

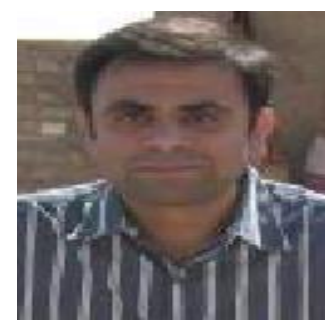

Raghu Raja is working as a Tech Lead with Financial Services in Accenture India. His current area of expertise Algorithm Design and programming.

Financial Services, Accenture.

e-mail: raghu.raja001@gmail.com

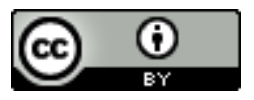

This work is licensed under a Creative Commons Attribution 4.0 International License. 